\section{Olesia PAVLIUK}

Higher State Educational Establishment of Ukraine «Bukovinian State Medical University», Chernivtsi (Ukraine)

o_pokorna@ukr.net

\section{Олеся ПАВЛЮК}

ВДНЗ України «Буковинський державний медичний університет», Чернівці (Україна)
THE INFLUENCE OF IRAN-CONTRA

AFFAIR ON U.S. RELATIONS WITH IRAN UNDER REAGAN ADMINISTRATION

\author{
ВПЛИВ СКАНДАЛУ \\ «IРАН-КОНТРАС» НА АМЕРИКАНО- \\ ІРАНСЬКІ ВІДНОСИНИ \\ ЗА АДМІНІСТРАЩІЇ Р. РЕЙГАНА
}

\begin{tabular}{l}
\hline Ключевые слова: внешняя политика, \\
внешнеполитический курс США, скандал \\
«Иран-контрас», Иран, политика \\
«сдержсивания», администрация Р. Рейгана, \\
стратегия обмена «оружия-на-заложников».
\end{tabular}

The greatest threat in the Persian Gulf region Reagan Administration saw in the Soviet Union influence, including because of military intervention in Afghanistan and its close ties with radical countries like Libya and Syria. The White House has focused its efforts In the Middle East at negotiations according a peace treaty between Israel and Egypt in 1978. Before the revolution in 1979 Iran was crucial to US interests in the Middle East. However, how the director of regional strategic programs of the Nixon Center and an expert in the National Security Administration under Reagan Administration J.argues, after the Islamic revolution, Iran became the periphery to US priorities in the region.

At the beginning of the Iran-Iraq war in September 1980 the US did not have an explicit position to

counter either pro-Soviet Iraqi or anti-American Iran. Reagan Administration declared at the beginning of the war of neutrality, which reflects the strategic, economic and political interests of the United States, including the rejection of the sale of arms to both sides; supporting international efforts for mediation in resolving the conflict; maintaining securi-
Павлюк Олеся. Влияние скандала «Иран-контрас» на аме-



В статье исследуются внешнеполитические подходы и средства налаживания двусторонних отношений Вашингтона и Тегерана и актическое введение политики «сдерживания» США в отношении

Учитывая возможности ИРИ по предоставлению влияния на слабление антиамериканской политики радикальных экстремистских организаций на Ближнем Востоке, администрация Р. Рейгана

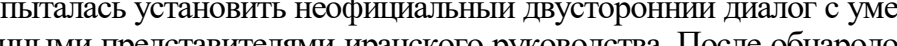
вания в США указанных тайных американо-иранских контактов и осуществление стратегии обмена «вооружение-на-заложников», в соединенных Штатах разразился внутриполитический скандал, свя作 сас», которая нанесла удар по доверию в США среди монархий итику в сторону проведения давления на ИРИ. Подтверждено, что наибольшим интересом США в ходе ирано-иракской войны рассматривался содействие как можно большему ослаблению соперниқами друг друга, чтобы ни одна из ближневосточных стран не смогстать гегемоном в регионе и помешать распространению американского влияния в Персидском заливе. ty of the Persian Gulf and against the spread of hostilities.

However, the Iranian theocratic elite concentrated its forces near theriver. Shatt al-Arab - the waterway on the border with Iraq. Fearing attack from Iran, which could threaten the weak oil-monarchies of the Persian Gulf, Jordan and even Israel, the United States revised its neutrality, preferring to back a more predictable Iraq in the Iran-Iraq war.

In early 1983 the United States also initiated the Operation Staunch - official plan aimed at cooperation with other countries to refuse to supply weapons to Iran, including equipment from the US to the Iranian soldiers who were trained and armed by the United States during their close cooperation with the Shah. For January 14, 1983 State Department instructed US embassies in the countries that could export arms to Tehran that they warned their governments to stop arms deliveries to Iran because of the great interest of the international community in achieving negotiations on ending the Iran-Iraq war.

Nevertheless, during his second term, Reagan administration decided to begin secret talks with 
Iranian authority. This initiative, according to $\mathrm{J}$. Kemp, was based on the mistaken belief that the Iranian regime included some "moderate" politicians who were ready to cooperate with the United States - at a time when others sought an alliance with the USSR.

Seeing the futility in implementing the policy of isolation regarding IRI in 1984, the administration of R.decided to review its foreign policy strategy towards Tehran. Thus Reagan suggested the establishment of political and economic relations with the "moderate" representatives of the Iranian government, which, in his view, could affect the softening of anti-American political course of Tehran, stop providing Iranian support to terrorist organizations in the Middle East, promote the cessation of Iran-Iraq war and to ensure that the IRI does not fall under Soviet influence.

In 1984 the CIA carried out the attempt to establish contact with Iranian "moderate" representatives. Thus, in November 1984 CIA agent T.Sheckley met in Hamburg with the former head of counter-intelligence of shah protection organization SAVAK M. Hashemi and he introduced him to M. Horbanifar, who then played an important role in the development of relations between the US and IRI, which became known as Iran-Contra or Irangate. M. Gorbanifar, a former SAVAK officer, one time worked with the CIA, engaged in trade of arms and kept relations with official Tehran after the Islamic revolution. M. Horbanifar made it clear that he is ready to take on a mediating role in the negotiations between the US and IRI according the "exchange" of the US hostages at weapon.

To implement the plan of military supplies to Iran through official public decision-making process was impossible and the staff of the National Security Council and the CIA began to look ways that are more "informal". Israel went at the forefront, and became the main channel for the implementation of US trade agreements with Iran. For political and legal reasons Israel could not supply weapons to a third country without obtaining prior permission from the government of the United States. In addition, Israeli Prime Minister Shimon Peres wanted to have firm guarantees that the US will full te Israel's arsenal of missiles after some of them Tel Aviv would supply in Iran. On the role of mediator between Israel and Tehran was invited M. Horbanifar. Soon he gave the Israeli side a list of weapons that needed to exchange for the release of American hostages from radical extremist organizations in Lebanon.

July 13, 1985 R.received from S. Peres message stating that Israeli agents in Iran can promote the liberation of all Americans trapped in Lebanon, if IRI receive 100 "TOW" missiles and it will serve as a pretext for the start of the US - Iran dialogue. After reading this message R.decided to launch a secret agreement with the Islamic Republic of Iran. August 6, 1985 Robert McFarlane recommended US President to convene a meeting of the National
Security Planning Group (NSPG) as the official meetings of the National Security Council attended a large number of employees. R., trying to discuss such sensitive issues in private, ordered to convene NSPG. The planning team included Secretary of State J. Schultz, Defense Minister K. Weinberger, CIA Director W., Vice President G. Bush, Admiral and J. Poindexter and R. McFarlane. According to $\mathrm{R}$ McFarlane, a few days after the meeting NSPG, R.called him to tell about his agreement to sell weapons to Iran with the help of Israel and reimbursement of appropriate compensation to Israeli government.

August 30, 1985 the first batch of 100 "TOW" missiles were bounced to Iran. However, the release of the hostages did not happen. According to M. Horbanifar this was due to the fact that agreed to supply 500 missiles "TOW", but was sent only 100 . Israel agreed to transfer another 400 missiles. However, after September 14, 1985 in the Iranian city of Tabriz were delivered 400 American missiles "TOW", only one American hostage was released the next day - priest B. Ware, captured in Lebanon by Shiite extremists. The White House were disappointed by the results of the first secret operation of exchange US weapon on hostages seized in Lebanon. In addition, any opportunities to expand American influence in Iran was not discovered and only one hostage was released.

Since the autumn of 1985 negotiations were restoring, at which the question of sending 80 antiaircraft missiles "Hawk" from Israel to Iran via Portugal was discussed. Third part of weapons had to be taken to IRI in November 22, 1985. However, operation failed, as the Portuguese government has refused to give permission for landing in its territory Israeli aircraft loaded with missiles on board. In this regard, Washington has decided to smuggle anti -aircraft missiles "Hawk" in Iran on its own plane. The CIA had to get new permits from governments of third countries for flying of its aircraft over their territory.

In the end the cargo was supplied in Tebriz with three days lateness by one plane and has only 18 missiles. None of American hostages was released and Iran refused from the cargo. One of the reasons, why the missiles "Hawk" didn't satisfied Teheran, was that they had Israeli labeling. This operation was first in Iran-Contra Affair, in which CIA took part directly that was conflicting to American legislation.

The main law that regulate the sale of weapon overseas is Control over Arms Export Act. It characterize the obligatory conditions, according which the US president can agree to re-export of American armament in third country (in this case from Israel to Iran). A list of conditions provides the written obligation of the third party not to sell this weapon to fourth country without appropriate permission from US government. White House didn't receive any written obligations from Iran. Moreover R.obliged to inform Congress beforehand, if the 
weapon costs more than $\$ 14$ million. Another law, under which the Irangate affair falls is National Security Act. According to its provisions the director of CIA and the heads of other foreign policy offices should in promptly inform the Senate Intelligence Committee about their activity. Any data on the covert supply of arms to Iran, which were carried out on the direct participation of the CIA, was not passed to the appropriate committees of Congress. Moreover, under the amendment "Hughes-Ryan" to the law on foreign aid, the CIA had no right to carry out any operations on IRI for as long as the president does not sign the so-called intelligence concluded regarding IRI. In late November 1985 the CIA urgently initiated the drafting of such conclusion of Intelligence Agency regarding the Islamic Republic of Iran, to give the appearance of legality of special services involvement in operations to supply weapons to IRI.

After such fiasco R. McFarlane resigned on November 30, 1985. December 4, 1985 Reagan appointed assistant to National Security Admiral J.. January 2, 1986 Israel offered Washington to release 20 members of the group "Hezbollah" from their prison and sent in Iran 4000 "TOW" missiles in exchange for the release of all American hostages in Beirut. Reagan approved the plan and signed the conclusion of the intelligence regarding Tehran, which gave the green light to resumption of deliveries of American weapons to Iran Israel. This conclusion highlighted a number of US goals in the "deal" with Iran: assistance of coming to power more moderate government in IRI; receiving important intelligence information that can be obtained in another way, the intentions of the Islamic government in Tehran according its neighbors and supporting of international terrorism; the release of American hostages in Beirut.

In January 24, 1986 the American plan of operation called "Restore" was developed. It was assumed that it will begin by transferring US intelligence information about Iraqi armed forces to Iran. After that, the Ministry of Defense of the United States had to transfer 1000 "TOW" missiles to the CIA, which transported them from the United States to Israel, and from there to Iran. The next day Iranians had to facilitate the release of US citizens taken hostage in Beirut, after which Washington would organize the supply of another 3,000 missiles to the IRI. The first batch of 500 missiles was delivered in February 18,1986 , and the second - 500 missiles in February 27, 1986 but none of the hostages was released.

M. Horbanifar explained to the disgruntled American side that the first thousand missiles intended to restore confidence in the good intentions of the United States to Iran, which were blown up in November 1985. The US government announced a desire to start direct contacts with the Iranian leadership. M. Horbanifar promised to organize everything, but, in turn, handed the list prepared by the Iranian side, the need for procurement of spare parts for missiles "Hawk" that Tehran really needed. M.insisted that senior Iranian officials agreed to accept the American delegation only if it personally bring with them the necessary spare parts. They agreed on the fact that a plane with a delegation from the US will be loaded the quarter of them. The rest would be taken after the release of the hostages. In May 25, 1986 a plane with an American delegation landed at the airport in Tehran. The same evening, negotiations began. However, a productive dialogue did not work, as from the Iranian side there were involved officials who did not have permission and status for the signing of the US-Iranian agreements.

Thus, the meeting that the United States conceived as a grand diplomatic "breakthrough" in USIranian relations turned to another great failure. In addition, in September and October 1986 Shiite extremists in Lebanon kidnapped three US citizen. Washington concluded that the main fault of the incident should be entrusted to M.who had no sufficient influence to force the Iranian leadership to abandon terrorist acts against Americans.

In November 3, 1986 about illegal US-Iranian relations became aware the international community. On this day in the Lebanese magazine "AlShira" were published the materials about the visit of the US delegation to the IRI. The source of sensational news "leak" may have been Iranian "moderate" leaders who understood that government Tehran will not forgive them agreements with the "Great Satan" and hastened to divert the blow from themselves. The message caused great resentment in the United States as a secret program of the arms supply to Iran, which was directed firstly by Israel, was implemented against the official policy of prohibition of weapons and transactions "Staunch". Money received from the sale of weapons to Iran, secretly were kept in Swiss banks to finance the Contras, anti-communist group in Nicaragua. Details of the Iran-Contra case was discovered in 1987 and became one of the biggest political scandals in US history.

Director of Center for Transatlantic Security, Head of the Middle East office in the National Security Council in the administration of J. Carter, R. Hunter believes that the strategy of sharing «armsfor-hostages" was important because of its significance for the Gulf region and US policy in strategically important regions. According to Lieutenant Colonel of US Marine Corps R. Bell, the supply of arms to Iran can be explained by two strategic considerations. Firstly, Israel, according to sources of the US government, first pointed the importance of the supply of arms to Iran, apparently acting on the basis of its long-standing "periphery policy", when it was trying to maintain good relations with the Iranian leadership. Secondly, it was strategically important for the US to improve relations with the Islamic Republic. Like his predecessors, President R.was concerned of the approach of the Soviet Union on American interests in the Middle East, and 
after the invasion of Afghanistan, the Soviet Union could take a course on Iran, and eventually control of the Gulf region.

Later, after the scandal concerning the case Irangate in 1986 economic relations between the United States and IRI in 1987-1988 were significantly complicated. In October 29, 1987 President R.signed Executive order12613, which highlighted that Iran has supported international terrorist organizations at the national level. Based on this Executive order, the United States introduced a ban on the import of goods of Iranian production. The ultimate goal of Washington was to made Iran to reduce the provision of financial aid to international terrorist organizations at the expense of export revenues. The White House has banned the import of Iranian goods of a total value of $\$ 1$ billion. American oil companies were also not allowed to import Iranian oil to the United States for consumption, but they were allowed to continue to buy Iranian oil for nonUS markets through their foreign subsidiaries. The US sanctions on IRI forced Tehran to seek new economic partners. However, Iran has deliberately avoided the traditional, pre-revolutionary suppliers from Western Europe (Germany, France and the UK) and Japan. Iranian government deemed that the American political influence could hinder free trade between Iran and Japan or Western Europe. Thus, economic ties of Iran with the United States significantly reduced, and trade and economic relations with some European countries, Eastern Europe and Islamic countries came to the fore.

Thus, since the early 1980 s the threat of security disbalance in the Middle East significantly increased, the Reagan administration gradually expanded US influence in the Gulf. The evolution of the president's foreign policy evidences about this processes. Continuing the Carter Doctrine, which declared the Gulf region a vital to US interests and approved the creation of a special military unit to protect them, R.implements the concept of "strategic consensus", which included the strengthening of US policy in the region of the Middle East and proclaims the Reagan Doctrine to achieve global impact of the US. Also, US President reorganizes, increases and improves the troops who had to respond to the hostilities in the Middle East region. Although R.saw in the spread of the Soviet Union the greatest threat, he also worried about intraregional instability that could be used by the Soviet Union in its favor. Iran-Iraq war and scandal IranContra were major challenges for the Reagan administration. To compensate for the loss of the American image because of the Irangate, which decreased US credibility among the monarchies of the Persian Gulf, R.transformed the regional policy in the direction of pressure toward IRI.

Reagan administration attempted to establish an informal bilateral dialogue with moderate representatives of the Iranian leadership, considering the possibility of IRI to influence the policy of anti-American radical extremist organizations in the Middle East. After re- vealence of these secret US-Iranian contacts in the United States exploded the internal political scandal involving the illegal sale of American weapons to Iran and support Contras in Nicaragua by this money. To compensate the loss of the American image from the Iran-Contra affair, which dealt a blow to US credibility among the monarchies of the Persian Gulf, Reagan transformed the regional policy in the direction of political pressure to IRI. Confirmed that the greatest interest in the US during the Iran-Iraq war was to promote the greatest weakening of two rival search other that none of the Middle Eastern countries could not become the leader in the region and prevent the spread of American influence in the Gulf. Thus, the possibility of the restoration of US-Iranian relations during the reign of R.were not fully realized.

\section{References:}

${ }^{1}$ The Iran primer: power, politics, and U.S. policy / ed. Robin Wright. - Washington, DC : United States Institute of Peace Press, 2010. - P. 134 ${ }^{2}$ Twinam. U.S. Interests in the Arabian Gulf / Joseph Wright Twinam // American-Arab Affairs. - 1987. №. - P. 5.

${ }^{3}$ Tyler. Officers Say U.S. Aided Iraq in War Despite Use of Gas [Електронний pecypc] / Patrick E.Tyler // The New York Times. - 2002. - 18Aug.- Режим дос-

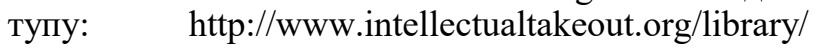
articles-commentary-blog/officers-say-us-aided-iraqwar-despite-use-gas

${ }^{4}$ Inouye. Report of the Congressional Committees Investigating the Iran-Contra Affair: with Supplemental, Minority, and Additional Views / Daniel K.Inouye, Lee H.Hamilton. - [S. 1.] : Government Printing Office, 1987. - P 159.

${ }^{5}$ The Iran primer: power, politics, and U.S. policy / ed. Robin Wright. - Washington, DC : United States Institute of Peace Press, 2010. - P. 135

${ }^{6}$ United States policy toward Iran: hearings before the Committee on Foreign Relations, United States Senate, One hundredth Congress, first session, January $14,16,23$, and 27, 1987. - Washington, 1987. $1321 \mathrm{p}$.

7. Report of the Congressional committees investigating the Iran-Contra affair (Stenographic transcript of hearings before the select committee on secret military assistance to Iran and the Nicaraguan opposition) // U.S. Senate select committee on secret military assistance to Iran and the Nicaraguan opposition. U.S. House of Representatives select committee to investigate covert arms transactions with Iran. Congress 100th. Session 1st. Washington, 1988. -Vol., S.. №100-216 ; H.Rept. №100-433. -P. 978.

${ }^{8}$. Deiatelnost SNB v peryod admynystratsyy R. Reihana: «Yran-kontras» [Elektronnyi resurs] - Rezhym dostupu:http://www.nationalsecurity.ru/

library/00031/00031 snbll.htm.

${ }^{9}$ Report of the Congressional committees investigating the Iran-Contra affair (Stenographic transcript of hearings before the select committee on secret military assistance to Iran and the Nicaraguan opposition) // U.S. Senate select committee on secret military assistance 
to Iran and the Nicaraguan opposition. U.S. House of Representatives select committee to investigate covert arms transactions with Iran. Congress 100th. Session 1st. Washington, 1988. -Vol., S.. №100-216 ; H.Rept. №100-433. -P. 1059.

10. Report of the Congressional committees investigating the Iran-Contra affair (Stenographic transcript of hearings before the select committee on secret military assistance to Iran and the Nicaraguan opposition) // U.S. Senate select committee on secret military assistance to Iran and the Nicaraguan opposition. U.S. House of Representatives select committee to investigate covert arms transactions with Iran. Congress 100th. Session 1st. - Washington, 1988. -Vol., S.. №100-216 ; H.Rept. №100-433. -P. 1060.

11. United States policy toward Iran: hearings before the Committee on Foreign Relations, United States Senate, One hundredth Congress, first session, January $14,16,23$, and $27,1987 .-$ Washington, 1987. - P. 1321 .

Khudolii A. Vplyv politychnykh stereotypiv na zovnishnopolitychnyi kurs administratsii Reihana / Anatolii Khudolii // Naukovyi visnyk Chernivetskoho universytetu : zb. nauk. pr. - Chernivtsi : ChNU, 2009. - Vyp. 486/487 : Istoriia. Politychni nauky. Mizhnarodni vidnosyny. - S. 160.

13. Deiatelnost SNB v peryod admynystratsyy R. Reihana: «Yran-kontras» [Elektronnyi resurs] Rezhym dostupu: http://www.nationalsecurity.ru/ library/00031/00031 snbll.htm.

14. McCormickJ. The Iran Arms Sale and the Intelligence Oversight Act of 1980 / James M.McCormick, Steven S.// PS: Political Science and Politics. - 1987. - Vol., №. - P.

15. Hunter. United States Policy in the Middle East / Robert F// Current History. - 1988. - №. - P.52.

16. United States policy toward Iran: hearings before the Committee on Foreign Relations, United States Senate, One hundredth Congress, first session, January $14,16,23$, and 27, 1987. - Washington, 1987. - P. 1321 .

17. KavoossiM. The Postrevolutionary Iranian Economy: Opportunities and Constraints / M.Kavoossi // Business Economics. - 1988. - Vol., №. - P.35.

Павлюк Олеся. Вплив скандалу «Іран-контрас» на американо-іранські відносини за адміністрації Р. Рейгана. В статті досліджуються зовнішньополітичні підходи та засоби налагодження двосторонніх відносин Вашингтону та Тегерану і фактичне запровадження політики «стримування» США щодо Ірану.

Встановлено, що оскільки на початку 1980-х рр. значно зросла загроза порушення безпеки на Середньому Сході, президентська адміністрація Р. Рейгана поступово розширює вплив США у Перській затоці та реалізує концепцію «стратегічного консенсусу», яка передбачала посилення американської політики в регіон i проголошує «доктрину Рейгана» для досягнення глобального впливу США.

Враховуючи можливості IPI з надання впливу на ослаблення антиамериканської політики радикальних екстремістських організацій на Близькому Сході, адміністрація Р. Рейгана спробувала встановити неофіційний двосторонній діалог 3 поміркованими представниками іранського керівництва.
Після оприлюднення в США зазначених таємних американо-іранських контактів та здійснення стратегії обміну «озброєння-на-заручників», у Сполучених Штатах вибухнув внутрішньополітичний скандал, пов'язаний з незаконним продажом американської зброї в Іран. Щоб компенсувати втрати американському іміджу від справи «Іранконтрас», яка завдала удару по довірі до США серед монархій Перської затоки, Р. Рейган трансформував регіональну політику у бік проведення тиску на IPI. Підтверджено, що найбільшим інтересом США у ході ірано-іракської війни розглядалось сприяння якомога більшому послабленню суперниками один одного, щоб жодна з близькосхідних країн не змогла стати гегемоном у регіоні і перешкодити поширенню американського впливу у Перській затоці.

Наголошується, що 1980-ті pp. були нестійким період у відносинах між Сполученими Штатами та Іраном і пройшли через чотири етапи: байдужості, ворожості, співпраці і вкінці протистояння.

Ключові слова: зовнішня політика, зовнішньополітичний курс США, скандал «Іран-Контрас», Іран, політика «стримування», адміністрачія Р. Рейгана, стратегія обміну «зброї-на-заручників».

Павлюк Олеся - викладач кафедри психологї та сочіології ВДНЗ України «Буковинський державний медичний університет», аспірант кафедри міжнародних відносин Чернівецького начіонального університету імені Юрія Федьковича. Коло наукових інтересів: зовнішня політика США, інтереси Сполучених Штатів на Близькому та Середньому Сході, самооиінка особистості, комунікативні здібності. Автор біля 40 наукових статей та публікацій, учасник міжнародних навчальних курсів, тренінгів та семінарів $в$ Німеччині, Польщі, Росії, Молдові.

Pavliuk Olesia - assistant of the Department of Psychology and Sociology of Higher State Educational Establishment of Ukraine "Bukovinian State Medical University», PhD student of the Department of International Relations of Yuriy Fedkovych Chernivtsi National University. Research interests: foreign policy of the U. S., interests of the United States in the Middle East, selfesteem, communication skills. Author of over 40 scientific articles and publications, a member of international training courses, workshops and seminars in Germany, Poland, Russia, Moldova.

Received 29-11-2015

Advance Acces Publischer: December 2015

(C) O. Pavliuk , 2015 